\title{
Optimization of preparation conditions for activated carbons from coconut husk using response surface methodology
}

\author{
I.A.W. Tan, A.L. Ahmad, B.H. Hameed* \\ School of Chemical Engineering, University Science Malaysia, Engineering Campus, \\ 14300 Nibong Tebal, Penang, Malaysia
}

Received 17 January 2007; received in revised form 12 April 2007; accepted 22 April 2007

\begin{abstract}
Coconut husk was used to prepare activated carbon using physiochemical activation method, consisted of potassium hydroxide (KOH) treatment and carbon dioxide $\left(\mathrm{CO}_{2}\right)$ gasification. The effects of the preparation variables which were activation temperature, activation time and chemical impregnation ( $\mathrm{KOH}$ :char) ratio on the adsorption capacity on methylene blue dye and carbon yield were investigated. Based on the central composite design (CCD), a two factor interaction (2FI) model and a quadratic model were respectively developed to correlate the preparation variables to the adsorption capacity and yield. From the analysis of variance (ANOVA), the most influential factor on each experimental design response was identified. The predicted adsorption capacity and yield after process optimization was found to agree satisfactory with the experimental values. The optimum conditions for preparing activated carbon from coconut husk were found as follows: activation temperature of $816^{\circ} \mathrm{C}$, activation time of $1 \mathrm{~h}$ and $\mathrm{KOH}$ :char ratio of 3.9 .
\end{abstract}

(C) 2007 Elsevier B.V. All rights reserved.

Keywords: Coconut husk; Activated carbon; Methylene blue; Central composite design; Optimization

\section{Introduction}

The presence of dyes in effluents is a major concern due to their adverse effect to many forms of life. The discharge of dyes in the environment is worrying for both toxicological and esthetical reasons [1]. Industries such as textile, leather, paper, plastics, etc., are some of the sources for dye effluents [2]. It is estimated that more than 100,000 commercially available dyes with over $7 \times 10^{5}$ tonnes of dye-stuff produced annually [3]. Methylene blue (MB) is the most commonly used substance for dying cotton, wood and silk. Though MB is not strongly hazardous, it can cause some harmful effects where acute exposure to MB will cause increased heart rate, vomiting, shock, Heinz body formation, cyanosis, jaundice, quadriplegia and tissue necrosis in humans [4]. Therefore, the treatment of effluent containing such dye is of interest due to its harmful impacts on the receiving waters.

In general, dyes are poorly biodegradable or resistant to environmental conditions [5]. Therefore it is necessary to treat

\footnotetext{
* Corresponding author. Tel.: +60 4599 6422; fax: +60 45941013.

E-mail address: chbassim@eng.usm.my (B.H. Hameed).
}

the wastewaters or industrial effluents containing dyes before being discharged into the waterways. A number of chemical and physical processes such as flocculation, chemical coagulation, precipitation, ozonation and adsorption have been widely used to treat dye bearing wastewaters [6]. However, the adsorption onto activated carbon has been found to be superior compared to other techniques for wastewater treatment in terms of its capability for efficiently adsorbing a broad range of adsorbates and its simplicity of design. However, commercially available activated carbons are still considered expensive. This is due to the use of non-renewable and relatively expensive starting material such as coal, which is unjustified in pollution control applications $[7,8]$. Therefore, in recent years, this has prompted a growing research interest in the production of activated carbons from renewable and cheaper precursors which are mainly industrial and agricultural byproducts, such as palm seed coat [9], rubber seed coat [10], jute fiber [11], rubber wood sawdust [12], pecan shell [13], corncob [14], bamboo [15], rattan sawdust [16] and oil palm fiber [17].

Coconut husk is the mesocarp of coconut and a coconut is consists of 33-35\% of husk. In Malaysia, about 151,000 ha of 